The work is attributed to Levi Stevens (d. 1832), an artist working in Montreal as early as 1810 and who painted with a fine academic hand. His career is unfortunately, poorly documented and at present nothing is known of his early life. He died during the cholera epidemic of 1832 in Toronto. ${ }^{1}$ The McCord has two other signed works by this artist (MEL985.162, MEL985. 163).

The McCord Museum's portrait collection is one of the major holdings in the country and portrays many of the prominent Canadians of the 18th and 19th centuries.

\title{
Note
}

1. Harper, Russell. Early Painters and Engravers in Canada, University of Toronto Press, Toronto. 1970, p. 298.

\section{Recent Additions to the David Hume Collection}

\author{
by Bruce Whiteman
}

Head, Department of Rare Books and Special Collections

The collection of books by and about Scottish philosopher David Hume (17 I 1-1776) is one of the major research collections in McGill's Department of Rare Books and Special Collections. It was begun in the late 1940s, and now contains the great majority of Hume's works in first editions, as well as later editions, translations, and many 18 th-century commentaries on Hume. The book collection also contains a number of items from Hume's library with his bookplate, and is supplemented by a group of 50 autograph letters, mainly addressed to Hume's friend the Countess de Boufflers.

The collection has benefited recently from two grants given by the Social Sciences and Humanities Research Council of Canada (SSHRC), the first in 1989 under the "Support to Specialized Collections Program" and the second in 1990 under the "Fleeting Opportunities Program."

The second grant allowed the Department of Rare Books to acquire a collection of 26 pamphlets and broadsides relating to the Douglas controversy of 1757 with which Hume was embroiled. His relative, John Home, had his play Douglas staged in Edinburgh beginning on December 14, 1756. Home was a clergyman, and the Church of Scotland's anathema against the theatre led to a controversy that produced a great many printed itens. Hume himself contributed to the war by dedicating his Four Dissertations (1757) to Home, and, as Hume's biographer has noted, "republication of the dedication in several of the weeklies and monthlies at both London and Edinburgh must have circulated it far beyond the sphere of those purchasing copies of Four Dissertations." I

The Douglas-related material acquired for McGill includes a copy of the first Edinburgh edition of the play (1757). A copy of the London edition of the same year, which may have bibliographical priority (though Gerald D. Parker chose the Edinburgh edition as his copy-text for the 1972 scholarly edition), was already in the Department of Rare Books' collection. 
Both sides of the controversy over Douglas are represented in the collection. As defenders of Home one finds, for example, Alexander Carlyle's satirical An Argument To Prove That the Tragedy of Douglas Ought to Be Publickly Burnt By the Hands of the Hangman (Edinburgh, 1757) and John Maclaurin's The Deposition, or Fatal Miscarriage: A Tragedy (Edinburgh, 1757), a satirical play about Home's treatment by the Church. The opposing side is perhaps better represented, and includes among other pieces The Player's Scourge; Or a Detection of the Ranting Prophanity and Regnant Impiety of Stage Plays, and Tbeir Wicked Enconvagers and Frequenters; And Especially Against the Nine Prophane Pagan Priests, Falsely Called Ministers of the Grospel, Who Countenanced the Thrice Cursed Tragedy Called Douglas by John Haldane, apparently a mad upholsterer, and John Witherspoon's A Serions Lnquiry Into the Nature and Effects of the Stage, Being an Attempt to Show, That Contributing to the Support of a Public Theatre, Is Inconsistent with the Character of a Christian (both published in Edinburgh in 1757). These pamphlets are accompanied by a number of leaflets and broadsides of songs, poems and advertisements relating to Douglas, of which two are unrecorded and several are known in only one or two copies. This collection joins a bound group of eight other Donglas-related pamphlets acquired in 1987, a volume which bears the bookplate of Baron Hume, David Hume's nephew.

Funds from the earlier SSHRC grant have been used to acquire 18 th-century books by and concerning Hume, with an unpredicted emphasis on continental translations. A copy of the third edition (1754) of the Political Discourses was acquired (copies of the first two editions already formed part of the collection), as well as copies of translations into French (Discours politiques de Monsieur Hume, Dresden, 1755) and Italian (Saggi politici sopra il commercio, [Venice?], 1767, and Parma, 1798). A set of the uncommon Dublin edition of The History of England (1772) was added to the collection, in addition to a set of a French translation unknown to Jessop, ${ }^{2}$ published in Yverdon in 1781, and two earlier French translations of individual parts of the work: Histoire de la maison de Stuart sur le trone d'Angleterre (Londres, 1763) and Histoire de la maison de Plantagenet sur le trone d'Angleterre (Amsterdam, 1765). Two Basle editions of Hume were acquired, a 1793 edition of the Essays and Treatises on Several Subjects and an unauthorized 1799 edition of the Essays om Suicide and the Immortality of the Soul. Three other French translations were also bought: the first French edition of Hume's autobiography, Vie de David Hume, écrite par lui-même (Londres, 1777), the 1788 "Londres" edition of the Oeuvres philosophiques, and the first French edition of the Essais philosophiques sur l'entendement bumain, which forms part of the Oeuves published by Schneider in Amsterdam in the years 1758-60.

Of the two rarest items acquired for the collection, the first is a copy of Todd's D issue ${ }^{3}$ of A True Account of the Bebaviour and Conduct of Archibald Stewart, Esq. (London, 1748). Stewart, Hume's friend and benefactor and Lord Provost of Edinburgh, was accused of surrendering the city to the Young Pretender and was tried on 12 related charges in 1747. Hume's pamphlet was written in his defence, and includes a postscript added after he learned in early November of Stewart's acquittal. ${ }^{4}$ The second piece is a copy of Sister Peg, or more fully, The History of the Proceedings in the Case of Margaret, Commonly Called Peg, Only Law ful Sister to John Bull, Esq. (London, 1761). The authorship of this uncommon book has been much disputed, and though David Raynor attributes it to Hume in his 1982 edition published by Cambridge University Press, many Hume scholars continue to hold that Adam Ferguson, not Hume, was its author. The McGill copy comes from the library of W.R. Scott, the author of a biography of Francis Hutcheson.

It has proved difficult to find copies of most of the 18 th-century "Humeana" lacking from the collection, but four interesting items have been acquired all the same. William Harris's An Historical and Critical Account of the Life and Writings of Charles I (London, 1758) includes an early mention of Hume's History of England. Joseph Priestley's Letters to a Pbilosopbical Unbeliever (Bath, 1780) comments extensively on Hume's treatment of natural religion, as does Joseph Milner's Gibbon's Account of Christianity Considered, Together With Some Strictures on 
Hume's Dialogues Concerning Natural Religion (York, 1781). Finally, a copy was acquired of one of the earliest German works on Hume, Friedrich Heinrich Jacobis David Hume uber den Glauben, oder Idealismus und Realismus (Breslau, 1787).

The McGill Hume collection is among the very best in the world, and it continues to grow. The entire collection will be catalogued by mid-1991 and is available to scholars, students and interested persons for consultation in the Department of Rare Books and Special Collections.

\title{
Notes
}

1. Ernest Campbell Mossner, The Life of David Hume (Austin: University of Texas Press, 1954), p. 362 .

2. T.E. Jessop, A Bibliography of David Hume and of Scottish Philosophy From Francis Hutcheson to Lord Balfour (New York: Russell \& Russell, I966).

3. William B. Todd, "David Hume: A preliminary Bibliography," in Hume and the Enlightenment: Essays Presented to Ernest Campbell Mossner, ed. William B. Todd (Edinburgh: Edinburgh University Press, 1974), pp. 192-3.

4. Mossner, pp. 182-6.

\section{Moshe Safdie's Archive}

\author{
by Irena Murray \\ Head, Blackader-Lauterman Library of Architecture and Art
}

\begin{abstract}
A key event in the development of our architecture collections took place in the BlackaderLauterman Library of Architecture and Art last year. In December 1990, after four years of negotiations, architect, author and educator Moshe Safdie, B.Arch. '61, LL.D. (honoris causa) '82, signed an agreement which made the University the sole depository for the extensive archive of his work. When fully constituted, Mr. Safdie's archive will not only include architectural plans, drawings, models, slides, photographs, and office files for all his projects, but also personal sketchbooks, manuscripts of books, correspondence, lectures, films, tapes, diskettes, and other research material, documenting the many aspects of Safdie's work.
\end{abstract}

The Canadian Architecture Collection (CAC) of the Blackader Library will face the challenge of organizing and describing the Safdie projects, to make them accessible to students and researchers. In order to cope with the sheer quantity and variety of material, a series of shipments is being planned by Safdie's principal offices in Boston and Jerusalem. The first shipment, received in February, consisted of two Canadian projects emblematic of Safdie's career: Habitat 67 and the National Gallery of Canada. Close to 150 rolls of architectural drawings and prints, 26 cartons of project files, 7 sketchbooks, as well as small architectural modes of the National Gallery spaces provide a unique insight in the creative process of the author of Beyond Habitat, For Everyone a Garden, Form and Purpose, The Harvard Jerusalem Studio, Beyond Habitat by Twenty Years, and, most recently, Jerusalem: The Future of the Past. 